\title{
Cosmic Perspectives and the Myths We Need to Survive
}

Charles H. Lineweaver

Australian National University

\begin{abstract}
Big history can be defined as the attempt to understand the integrated history of the cosmos, Earth, life and humanity. Cosmic perspectives and biological evolution are the main scientific ingredients that can convert and broaden history into big history. The aim of this paper is to describe a dilemma that such a scientific, Darwinian big history must face: the inevitable incompatibility between an objective scientific s earch for truth a nd an evolutionary compulsion for brains to harbor useful fictions - the myths we need to survive. Science supports both sides of this dilemma. New and improved cosmic perspectives can't just be scientifically accurate. To be of use they must leave room for the myths we humans need to survive. But, what are those myths? I discuss and question whether the following ideas qualify as such myths: a belief in an objective meaning for human life, humanism/speciesism, human free will and stewardship of the Earth.
\end{abstract}

Correspondence | Charles H. Lineweaver, charley.lineweaver@anu.edu.au

Citation | Lineweaver, C. H. (2019) Cosmic Perspectives and the Myths We Need to Survive. Journal of Big History, III(3); 81 - 93.

DOI | https://doi.org/10.22339/jbh.v3i3.3350

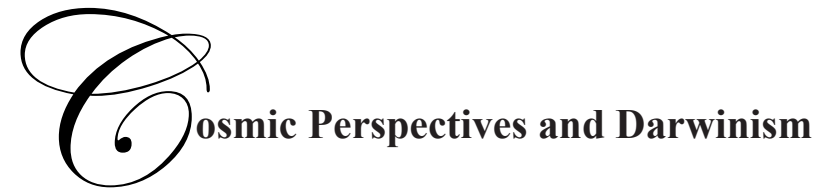

Like all organs, our brains have evolved to help us survive. They have evolved to see the world in useful ways that promoted the survival of our ancestors. This presents scientists with a dilemma: we are looking for the truth, but the Darwinian truth about evolution suggests that when useful survivalpromoting fictions conflict with the truth, we can prefer the useful fictions. How can we scientists insist on the truth when the same brains that are searching for truth sometimes prefer useful fictions for perfectly legitimate scientific reasons that Darwin helped us understand.

The myths we have told ourselves for roughly two million years have helped us survive. But how much survival value do these parochial myths still contain for 8 billion people on a shrinking planet? What myths do we still need? The answers to these questions set the agenda for the construction of big history and modern cosmic perspectives.
Every human culture has a worldview (Brown 1991) - a cosmic perspective - a weltanschauung a context within which the world is explained, the gods are propitiated, and believers are protected. Most traditional worldviews have been blatantly selfserving: We are "the people". We are the good Greeks. They are the bad barbarians. We are the chosen ones. The Earth has been made for us. People of my religion go to heaven - believers in other religions go to hell. For such myths to become so ubiquitous, groups who thought they were the best people on Earth and favoured by the gods, must have had an adaptive advantage. These beliefs made us proud, gave us confidence and promoted our survival.

Scientific worldviews are slowly displacing myths. Darwinian evolution continues to supplant anthropocentric creation stories. The most influential scientific revolutions are ones that change our view of ourselves - the ones that change our understanding of how we got here and how we fit in. This is because the meaning or purpose we find in life is strongly linked to who we think we are. The Copernican and Darwinian 
revolutions changed our worldview and undermined traditional beliefs about our privileged place in the universe (Kuhn 1957, 1962). They removed humans from the center of the universe and reduced our traditional pride and confidence in ourselves. But at the same time, they gave us a new pride in how much we have figured out about the universe and our place in it.

When told about Darwin's idea that we evolved from ape-like ancestors (Darwin 1859, 1871), an elderly Victorian woman is reputed to have replied, "Let us hope it is not true, but if it is, let us pray it does not become widely known." If our local myths have taught us that our true position is in first class next to gods and angels, then it is painfully degrading to recognize our true place among terrestrial tetrapods.

Sociobiology (Wilson 1975) is the systematic study of the biological basis of all social behavior. It can be understood as a continuation of the Darwinian reassessment of who we think we are and a challenge to human exceptionalism. Sociobiology applies Darwinism to human society and human psychology (Wilson 1978), and has provoked such fierce resistance from

the humanities and social sciences, that the conflict became known as the sociobiology wars (Segerstrale 2000). The multifaceted resistance to Darwinism is described in "Darwin's Dangerous Idea" (Dennett 1995, see also Cronin 2013). 


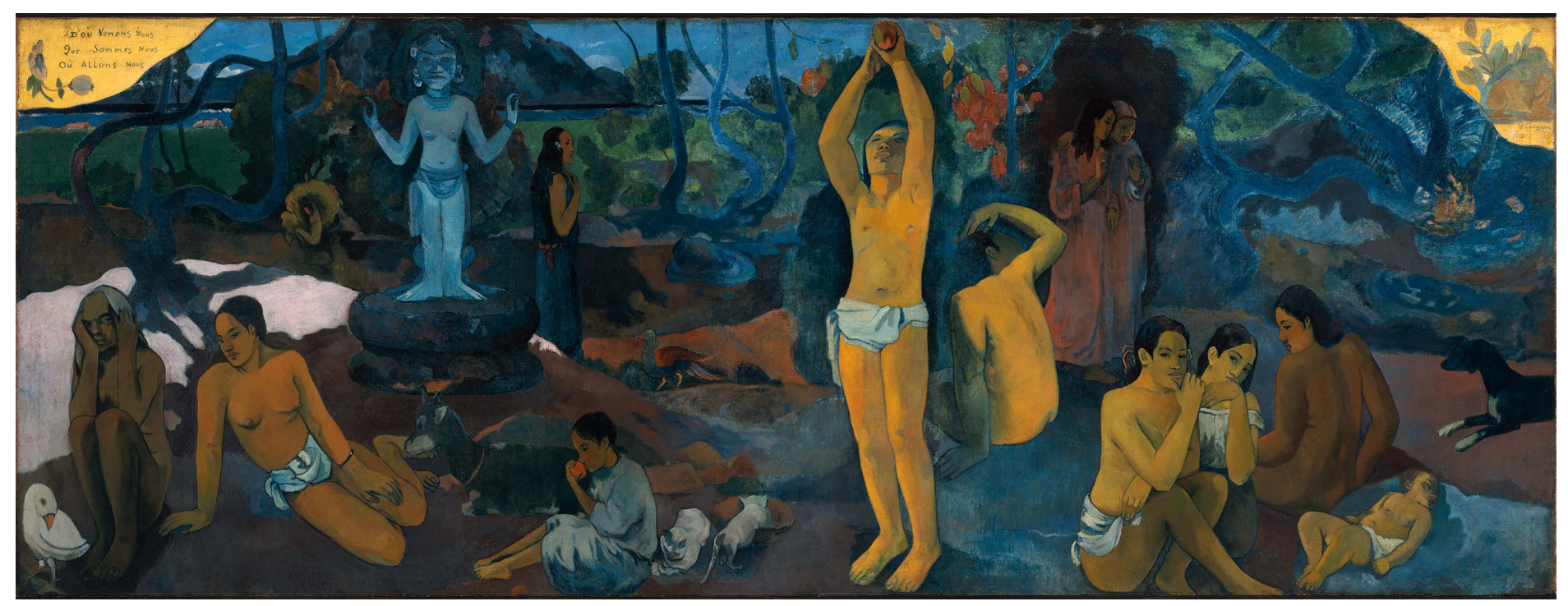

Figure 2. In 1897 (fifteen years after Figure 1) in French Polynesia, post-impressionist Paul Gauguin painted "Where do we come from? What are we? Where are we going?" These fundamental anthropocentric questions are inscribed in French in the upper left of the painting. Gauguin's images suggest that he is not looking for scientific answers to these questions. The beginning of a human life is on the right, the end of a human life is on the left. There is a blue idol of a god, maybe some worshipping going on, but there are no evolving monkeys. In debt and despair, Gauguin painted this while mourning the sudden death of his nineteen-year-old daughter Aline. After finishing this painting, Gauguin unsuccessfully tried to kill himself with arsenic. (Image from wiki Commons, Museum of Fine Arts, Boston)

Perhaps motivated by witnessing the nationalistic delusions that led to the Great War, Bertrand Russell (1919) described the prevalence and usefulness of comforting fictions,

Every man, wherever he goes, is encompassed by a cloud of comforting convictions, which move with him like flies on a summer day.

Russell (1928) thought we should push back against this "cloud of comforting convictions":

There is a stark joy in the unflinching perception of our true place in the world, and a more vivid drama than any that is possible to those who hide behind the enclosing walls of myth.

However, in our confident promotion of scientific perspectives in the modern world, we need to face the question: How stark can the scientific perception of our true place in the world become before our perception loses its survival value? How unflinching can we be before our stalwart behaviour becomes detrimental to our survival? Isn't flinching sometimes adaptive? If a scientific vision of our true place in the universe is too stark - if our true place is too bleak, meaningless and unable to sustain hope and optimism - no one will want that vision - and those who adopt it will probably be at a disadvantage.

Myths - like Russell's "cloud of comforting convictions" - sustain us. And sometimes we need sustaining. Ourstomachs empty, our babies and children starving, our loved ones succumbing to plague and death - the worldviews of our hunting and gathering ancestors were based on beliefs that promoted survival in such conditions. If we got too weak or discouraged, if our worldview did not maintain our courage in the face of adversity, our enemies sensed our vulnerability and attacked. Comfort cannot be easily discounted or 
trivialized in a mysterious, intimidating and dangerous world. Where can I get my next meal? How can I gather enough resources to attract a mate and reproduce. How can we keep our children alive? Most of our myths and morality evolved to help us successfully answer these questions - questions that have little to do with truths about the big picture, heliocentrism or our evolutionary relationship to monkeys.

Has the world become safe enough to dispense with myths? We rich, well-fed moderns, armed with antibiotics and ensured of our children's survival have other means to find comfort. Now that starvation no longer knocks at our doors, now that infectious disease is no longer due to the wrath of the gods, now that we have outsourced retribution and the enforcement of justice to the state (Diamond 2008), many of us feel comfortable discarding our culture's traditional myths and replacing them with less flattering truths that our egos can still put up with. If we are confident in who we are, we can afford to question the traditional beliefs that have given us importance and meaning. But how unflattering can the truths become and still promote our survival? Can we handle the unmythologized truth? For those of us trying to construct big history and better cosmic perspectives, the question becomes: How much truth can they contain and still perform their function?

\section{Useful Untruths}

Whatever may be the innermost feelings of individual scientists, science itself works by rigorous adherence to objective values. There is objective truth out there and it is our business to find it.

(Dawkins, 2017, p 7)

Scientists are trained to look for the truth.

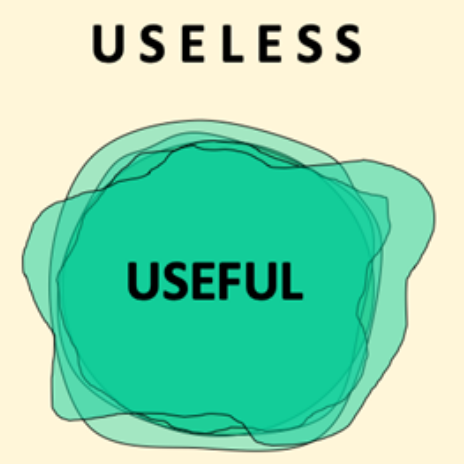

UNTRUTHS

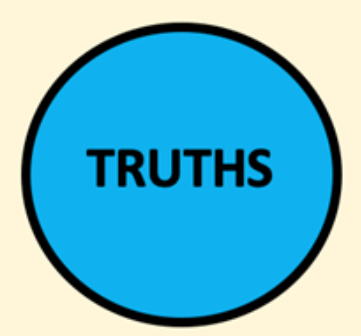

Figure 3 On the left, concepts are divided into useful (inside the green circles) and useless (outside the green circles). Since "useful" can be time- and context-dependent, we show multiple boundaries between useful and useless. On the right, concepts are divided into truths (inside the blue circle) with untruths (outside the blue circle). Scientists often say they are looking for truth and naively assume that all truths are useful. In contrast, Darwinian evolution produces the useful with no assumptions about truth. In the next figure, we combine these two concepts to show that not all truths are useful and not all useful concepts are true.

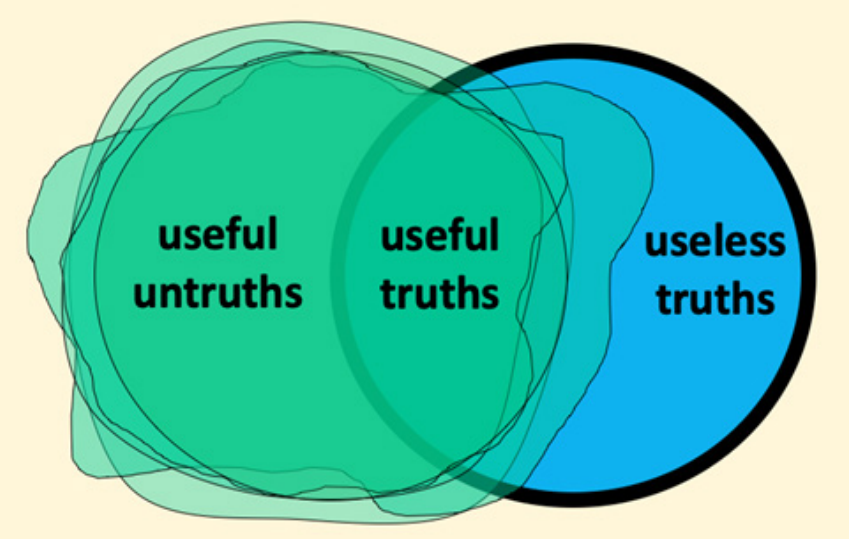

Figure 4. Here we combine the two circles from Fig. 3. The useful truths in the central overlapping region are both useful and true. Modern medicine is based on the useful truths of microbiology. Defenders of science are all about how big this overlapping region is. It is big, but it is not the only part of the diagram. There are three other parts: 'useful untruths' on the left, 'useless truths' on the right and the whole diagram is surrounded by 'useless untruths'. 
When we analyze data, we try to do so dispassionately. We suppress our hopes - we fight what we want to be true, so that the truth can emerge more easily. We search for objective truth through the emotional storms and confusion of our own subjectivity. In the scientific hunt for the truth, the useful often shows up. In the Darwinian hunt for the useful, the truth often shows up. There is often a correlation between true and useful. Let's ignore this well-known and popular overlap of truth and usefulness and consider the usefulness that does not overlap with the truth (Figs. $3 \& 4)$.

Here are some examples of the things that fall into the four categories of Figure 4:

1) Useful truths (in the middle). Modern medicine and technology are based on useful truths from biology, physics and chemistry. Useful truths underpin applied science of all kinds, e.g., the production by modern agriculture of drought-tolerant crops, cars, computers, the internet, cell phones and x-ray machines, etc.

2) Useless truths (on the right): knowledge so detailed that nobody cares, e.g. the positions and velocities of all the nitrogen molecules in your room exactly $\pi$ seconds after you read this sentence, the idea that your own group, or your own children are not objectively better than other groups and other people's children. Mathematicians generate mountains of useless truths, but occasionally, a new branch of physics finds a use for some of them. Thus, occasionally useless truths are converted into useful truths by the changing boundary of what is useful.

3) Useless untruths (area surrounding both circles): incorrect data or bad information that no one cares about, or uses, or believes.

4) Useful untruths (on the left): arguably the most interesting set. These include myths, religion, self-deception (Trivers 2000), flattery of self, flattery of others, dreams, nightmares, flights of fancy, belief in the superiority of your in-group (tribalism, nationalism), dehumanization of the members of the tribes you are fighting (xenophobia and racism), selffulfilling prophecies, placebo effects. I will argue that humanism/speciesism and our belief in human free will are also in this category.

In Wilson's 2013 "Letters to a Young Scientist" he reminds us why we do science and why science is right and religions are wrong:

\begin{abstract}
The scientific method has been consistently better than religious beliefs in explaining the origin and meaning of humanity...Colorful they are, and comforting to the minds of believers, but each contradicts all the others. And when tested in the real world they have so far proved wrong, always wrong.
\end{abstract}

Something is amiss here. Evolution (and the human brain that it produced) shouldn't care if religious beliefs are "wrong, always wrong" as long as they keep their believers alive preferentially over non-believers. Wilson's sociobiology is all about the idea that brains (like livers and lungs) are organs that have been selected to keep us alive and reproduce (Barkow et al. 1999). It seems strange for the founder of sociobiology to expect adaptive religious beliefs to be true. Brains and their contents have been selected to support useful cosmic perspectives (not necessarily truthful ones). If true ideas are useful, then brains that harbour them will be selected for. If false ideas are useful then brains that harbour them will be selected for. Religious beliefs have been tested in the real world. That is why there are so many extant believers. On this Darwinian view, we expect our cosmic perspectives (about questions such as "Who are we?", "What is our place in the universe?", "What is the origin and meaning of humanity?") to be useful, comforting, and an aid to survival, but not necessarily truthful. The new scientific light that Darwinism shines on the battle between truth and useful fictions, is that there 
is no higher priority than survival. No truth-seeking mechanism, like science, can succeed if it undermines survival.

Wilson wrote "The scientific method has been consistently better than religious beliefs in explaining the origin and meaning of humanity." But Gauguin et al are not expecting a scientific explanation of the meaning of their lives. Scientific answers are not what they want to hear. Our traditional expectation is that truly "meaningful answers" must give the leading role to humans. But what ultimate "meaning" can science explain when there isn't any ultimate meaning? For Gauguin, the monstrous mindlessness of the cosmos is not among the acceptable explanations for the death of his nineteen-year-old daughter Aline. At such times, scientific views play second fiddle to myths, because we believe we are important and need input to support this idea that science seems unable to provide.

\section{What are the myths we need to survive?}

\section{Weinberg's pointlessness}

Is there any meaning in all the information that scientists have amassed about our place in the Universe? In one of the most cited passages in popular science at the end of his book "The First Three Minutes" (1977) about the big bang origin of the universe, Steven Weinberg (winner of the 1979 Nobel prize for physics) muses:

It is almost irresistible for humans to believe that we have some special relation to the universe, that human life is not just a more-orless farcical outcome of a chain of accidents reaching back to the first three minutes, but that we were somehow built in from the beginning... Below, the Earth looks very soft and comfortable - fluffy clouds here and there, snow turning pink as the Sun sets, roads stretching straight across the country from one town to another. It is very hard to realize that this all is just a tiny part of an overwhelmingly hostile Universe. It is even harder to realize that this present Universe has evolved from an unspeakably unfamiliar early condition, and faces a future extinction of endless cold or intolerable heat. The more the Universe seems comprehensible, the more it also seems pointless.

I'm sure Weinberg's expectations are to blame for making the Universe seem pointless to him. The universe is only pointless to the degree that he insists it have a point. After having attracted some criticism for his use of the word "pointless", Weinberg backpeddled and articulated his thoughts a bit more carefully (see Lightman 1990, p 466)
If you say things are pointless, you have to ask "Well, what point are you looking for?" And that's what's needed, I think, to be explained. What kind of point would have been there that might have made it not pointless. That's what I would really have to explain.

But Weinberg didn't go on to explain. Apparently, he was unable to describe a universe with a point - a universe in which humans have some objective meaning that science could discover. This is a relief in some quarters: 'If there is no meaning in it,' said the King, 'that saves a world of trouble, you know, as we needn't try to find any' (Carroll 1865).

\section{Chesterton's Conservatism}

The removal of useful untruths from our cosmic perspective seems to be a goal of science. Chesterton (1929) has some advice for reformers who would like to displace traditional myths; don't take down a fence until you know the reason it was put it up.

In the matter of reforming things, as distinct from deforming them, there is one plain and simple principle; a principle which will probably be called a paradox. There exists in such a case a certain institution or law; let us say, for the sake of simplicity, a fence or gate 
erected across a road. The more modern type of reformer goes gaily up to it and says, "I don't see the use of this; let us clear it away." To which the more intelligent type of reformer will do well to answer: "If you don't see the use of it, I certainly won't let you clear it away. Go away and think. Then, when you can come back and tell me that you do see the use of it, I may allow you to destroy it.

Heeding Chesterton, before we tear down more of our $\sim 2$-million-year-old myths, we should figure out why they are there, so we can keep the ones we still need. What myths do we still need to tell about ourselves?

\section{Harari's Fictions}

Yuval Harari's recent books about humans and big history have been hugely successful (Harari 2015, 2017,2018 ). He describes the beginnings of science as the discovery of our own ignorance. He postulates that our success as a species is mostly due to our ability to tell stories and to believe them. Our advantages over other species he chalks up to our credulity and our ability to delude ourselves into believing myths and fictions.

\section{You could never convince a monkey to give you a banana by promising him limitless bananas after death in monkey heaven (Harari 2015)}

Among our most successful fictions are concepts that most people would not consider fictions: nations, money, democracy, capitalism, corporations, religion and human rights. The important question he keeps asking is: What are the myths we humans need to survive?

Scientists are uncomfortable with this question and cannot easily address it within the confines of the scientific method. We are not necessarily looking for ideas that will help us survive. We are hunting for the truth, wherever that leads us. We are not trained to care about the survival implications of our truths. Astronomers do not request ethical clearances, or fill out health and safety impact statements before announcing their discoveries to the world. Most cosmologists are blissfully unaware of the effect their newly discovered truths will have on people. We do not know whether the idea of a multiverse will terrify us with yet another layer of anonymity, or help us become more humble and survive the next millennium. The idea of assessing the value of a scientific worldview has been limited to "Is it true?" not "Does it contribute to our survival?"

To make a scientific worldview psychologically useful and more palatable to people who need more meaning and purpose in their lives, should we include a bit of human-centered mythology in our worldview? Fantasy writer P.C. Hodgell (2000) has little sympathy for such compromises between myth and science:

That which can be destroyed by the truth should be.

This attitude seems unnecessarily combative and ignores the nuances of the changing boundaries of what is "useful" (Figs. $3 \& 4$ ). Rather than seeing it as a battle, the relationship between truths and useful untruths can be seen as a symbiotic relationship that can be nudged conservatively (in Chesterton's sense): don't destroy a myth until you know why it is there.

\section{Science and Survival}

What is the purpose of life? Am I important? How hard should I fight to stay alive? How hard should I fight for my tribe? Can I find food? - or should I just give up? Scientific worldviews have effects on our answers to all these existential questions. And the effects are rarely as life-affirming as the effects of traditional myths. Science (and Darwinism in particular), erodes the trust that many people have had in their myths. This is one reason the leaders of native peoples all over the world are ambivalent about, or positively against, contributing their knowledge and 
genes to modern science (Marks 2009) - an undertaking whose main result will be to undermine native traditions even faster.

In a life short and uncertain, it seems heartless to do anything that might deprive people of the consolation of faith when science cannot remedy their anguish. Those who cannot bear the burden of science are free to ignore its precepts. But we cannot have science in bits and pieces, applying it where we feel safe and ignoring it where we feel threatened again, because we are not wise enough to do so.

(Sagan 1997, p 279-80)

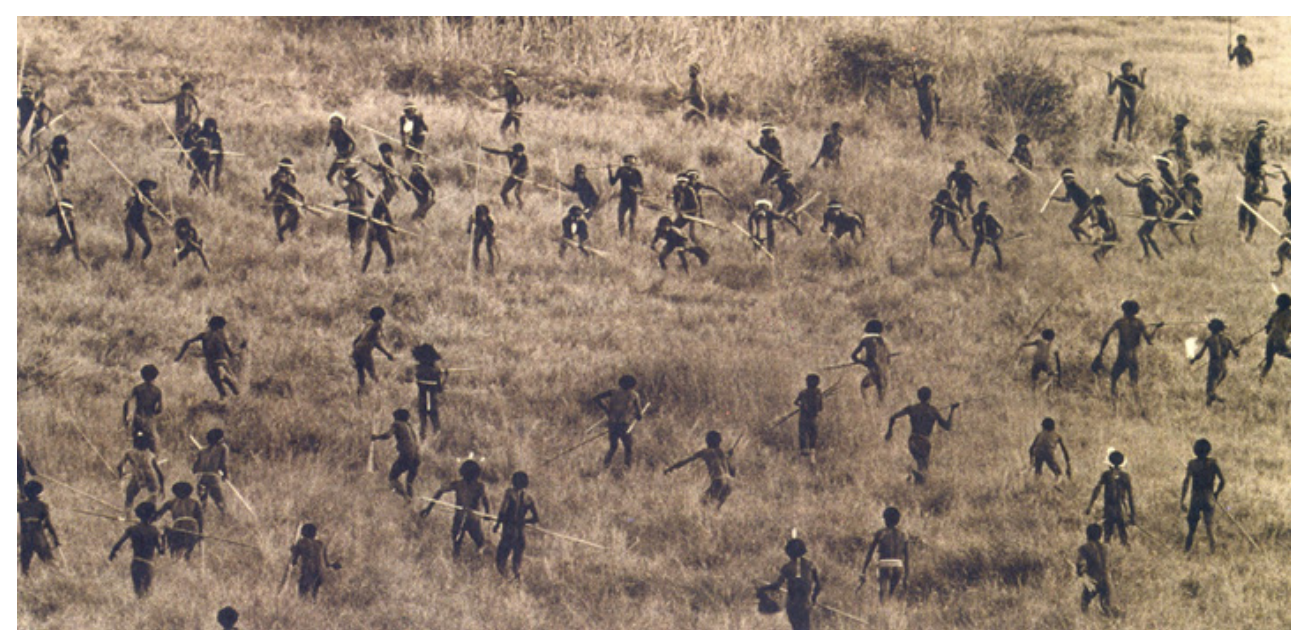

Figure 5. A skirmish between two Dani tribes in the Baliem Valley of the New Guinea Highlands. Their myths are mutually exclusive. Each thinks their group is better. The nationalistic myths of nation states are also mutually exclusive. Whether national myths promote or inhibit the survival of nationalists is an on-going concern of humanity. (photograph by Karl G. Heider, Peabody Museum of Archaeology and Ethnology, Harvard University)

Sagan writes that "we cannot have science in bits and pieces"? But, isn't that the way most people have science? And if we are "not wise enough" now, can't we learn and become wiser? Can't we measure people's worldviews and then later keep track of whether they survive or not? If we want to displace traditional myopic myths, the survival value of our scientific worldview needs to outweigh the survival value of traditional self-serving worldviews. Sagan makes a similar suggestion:

There is some cost-benefit analysis which must be applied, and if the comfort, consolation and hope delivered by mysticism and superstition is high, and the dangers of belief comparatively low, should we not keep our misgivings to ourselves? (Sagan 1997, p 281)

Telling a non-scientific, illiterate society of hunter/ gatherers about their African origins can be equivalent to insulting their gods and undermining their creation stories (Larson 2006). Native peoples are having their cultural identities pulled out from under them. Many cultures and languages are disappearing (Crystal 2000,
Sutherland 2003). The rapid pace of technology has now placed all of us in the same position of rapidly losing our traditional myths. Like native peoples, we are all having our identities transformed. Our regional cultures are being taken away from us and replaced by a global culture homogenized in a technological blender of mass media, modern transportation and global communication (Habermas 2001).

\section{Old Myths in the Modern World}

It is not difficult to recognize the biases and lies of our current cosmic worldviews. They are the same self-serving lies that we have been telling ourselves for several million years - that our tribe is the best that our species is the best - that the out-group should be ignored, left to die, or be killed.

The most common form of myth creation is ignoring or being unaware of the big picture and telling only part of the story - telling the truth, but not telling the whole truth. If I am pretending to tell the story of all humanity, but I am only telling the story 
of one nation, then I am creating a nationalistic myth. Even if the story of the one nation is correct in every detail, it is still a myth because it is presenting itself as something larger than it is. This is the unappreciated myth-creating power of editing, or just ignorance. The debunking of these myths - partial stories parading as the full story - is one of the biggest problems that big history has to solve.

In school, most of us were taught the history of the particular nation where we were brought up. We were taught national history. I was taught American history. The history I was taught was not incorrect, it was just that it left out other nations and other peoples. It largely ignored the native peoples of North America. The story did not explicitly state that our nation is the best. It was just that other nations were ignored. Nation states all over the world continue to indoctrinate their children with these myths created by restrictive national histories - the products of conveniently incomplete truths.

Big history tries to remove the blinkered myopia and biased legacy of such national histories by considering everyone. Big historians are trying to amalgamate national histories into the history of humanity (Harari 2015). They are also trying to include the scientific history of the universe - not only all people, but all biology. And not only all biology, but all matter (e.g. Christian 2005, 2018, Rodrigue, Grinin \& Korotayev 2017). But big historians have an extra burden that scientists don't. Big historians are burdened by the adherence to a narrative structure meant for consumption by one species. Like Weinberg (1977), a human audience naturally yearns for the largest role possible for humanity.

Some scientists focus their attention largely on the science of man and ignore other species (like my history teachers ignoring other nations). They are not telling explicit lies. The details about humanity are often correct. What is incorrect is the pretense of presenting the full picture while presenting a blinkered vision in which only one species is important. Jacob Bronowski's books "The Identity of Man" and "Ascent of Man” (Bronowski 1966, 1973) are good examples of telling the story of one species and pretending it is the story of all life. Most of the facts are correct, but the exclusion of non-humans creates a flattering myth:

For me, the understanding of nature has as its goal the understanding of human nature, and of the human condition within nature... the human being is a mosaic of animal and angel. (Bronowski 1973)

Based on such flattering myths, the "science" of human uniqueness is thriving. This biased politicized science is a good example of why science should not traffic in self-serving myths. It is biased because it doesn't ask "What kind of an animal are humans?" Rather it assumes we are better than other animals and asks, "What makes us better?" Like the myths of nationalism, it is a myth based on incomplete truths and an emotional appeal to human exceptionalism. It tells us that "Humans are unique" and ignores the more complete truth: "Humans are unique, just like every other species."

As tribes become nation states, tribalism becomes nationalism. As nations recognize other nations and our common humanity, nationalism becomes humanism. Our in-groups have gotten bigger, but having a larger in-group solves one problem and creates another - it just moves the problem to a larger scale (Diamond 1997, Harari 2015). Increasing the size of the "ingroup" from a nation to include all humanity may reduce wars between nations but may increase the war between species - between humanity and the rest of the biosphere. Valuing Homo sapiens above all other species is leading to the environmental degradation of the planet (Rees 2003, Grooten \& Almond 2018) and ultimately, this isn't good for anyone.

In more traditional self-centered myths, the "self" meant, my tribe or my ethnic group. But in 
the aftermath of World War II, the idea that we are all people became a valuable new progressive myth (Harari 2015). Despite speaking different languages, and being of different religions and ethnic groups, the United Nations was created and the Charter of Human Rights was agreed to.

For Bronowski and most modern myth makers the new "self" in "self-centered myths" has become all humanity. This is a powerful antidote to tribalism and racism, but it still excludes other apes and all other species. Thus, humanism has a downside -- speciesism: the idea that my species is the best species. Unlike racism, speciesism has not yet been recognized as a self-centered prejudice harmful to the Earth. It is still seen in a positive light as a tool against racism.

From an ecological point of view, humanism is a subtle way of saying that the species Homo sapiens is more important than other species. Many humanists are keen on keeping chimps at arm's length. This is because, if humans are to be recognized as a firstclass group, distinct and better than other species entitled to more rights than other species - then a larger biological distance helps justify these human rights and privileges. Some of the useful untruths of speciesism have been undermined by the work of Jane Goodall (2010) and DNA sequencing of our closest cousins, chimpanzees (Mikkelsen et al 2005).

\section{Free will and Stewards of the Earth}

Scientific revolutions over the past few hundred years have changed our view of the world (Lucretius $\sim 50$ BC, Huxley 1863, Wallace 1904, Harari 2015). And they have changed our self-image. Many more changes are on the way. So many that Cronin (2013) thinks we have much to fear from our continued scientific attempts to understand ourselves. We are in a fight to protect human dignity and agency and free will and our speciesism. How else can we sustain the myth that our species is more important than all other species?
The scientific examination of the concept of free will is an example of something we should fear because it could have dangerous implications for our self-image:

\begin{abstract}
When we consider whether free will is an illusion or reality, we are looking into an abyss. What seems to confront us is a plunge into nihilism and despair.
\end{abstract}

(Dennett 2008)

Sam Harris and Richard Oerton strongly disagree with Dennett's topography (Harris 2012, Oerton 2012, 2016). They think that the illusion of free will is a detrimental perpetuation of savagery into the modern word (see Clark's 2013 review of Oerton 2012).

The useful fiction of free will and the illusion of control has produced a "we are the stewards of the Earth" mentality (Grinspoon 2016). But, we are certainly not acting like stewards when we clear land and monopolize it with monocultures for our growing numbers (Hardin 1993), displacing and significantly reducing populations of insects, birds and other wildlife (Diamond 2010, Wikelski \& Tertitski 2016, Grooten \& Almond 2018). Our self-serving speciesism gives our needs higher priority than the needs of other species, and has become a justification to expropriate resources everywhere and pollute the entire planet with our waste products (Daly \& Farley 2010, Lineweaver \& Townes O'Brien 2015). While constructing a cosmic perspective, keeping the good parts of humanism while abandoning these speciesist implications may enable us to change and survive.

\section{Conclusion}

Cosmic perspectives and biological evolution are the main scientific ingredients that can convert and broaden history into big history. However, when adding these ingredients, there is an inevitable incompatibility between the scientific search for truth and the evolutionary compulsion to believe in adaptive useful fictions. Self-serving beliefs have 
been a prominent universal feature of human cultures for sound evolutionary reasons. I point out and analyze the concept of useful untruths, and ask: What myths do we still need to survive? Following Chesterton, I suggest that before displacing a myth, we should find out what its purpose is and determine if we still need it to survive. I suggest this is the path forward for creating better cosmic perspectives. In particular, I discuss and question the potentially useful untruths of i) an objective meaning to human life, ii) a bigger ingroup and the double-edged nature of humanism iii) free will and the supposed human stewardship of the Earth.

\section{References}

Barkow, J.H., Cosmides, L. \& Tooby, J. 1999 The Adapted Mind: Evolutionary Psychology and the Generation of Culture, Oxford Univ. Press, Oxford, UK.

Bronowski, J. 1966 The Identity of Man, American Museum Science Books, Natural History Press.

Bronowski, J. 1973 The Ascent of Man, British Broadcasting Corporation, London, UK.

Brown, D.E. 1991 Human Universals, New York, McGraw-Hill.

Carroll, L. 1865 The Annotated Alice (1960): Alice's Adventures in Wonderland \& Through the Looking Glass, Bramhall House.

Chesterton, G.K. 1929 “The Drift from Domesticity" in The Thing, https://www.chesterton.org/lecture-57/, accessed 1 February 2019.

Christian, D. 2005 Maps of Time: An Introduction to Big History, University California Press.

Christian, D. 2018 Origin Story: A Big History of
Everything, Little, Brown and Company.

Clark, T. 2013 The Rise of the New Determinists. Book review of The Nonsense of Free Will by R. Oerton (2012) https://naturalism.org/resources/bookreviews/the-rise-of-the-new-determinists.

Cronin, H. 2013 "What *Should* we be worried about?" $\quad$ http://edge.org/response-detail/23851, accessed 1 February 2019.

Crystal, D. 2000 Language Death, Cambridge University Press.

Daly, H.E. \& Farley, J. 2010 Ecological Economics: Principles and Applications ( $2^{\text {nd }}$ ed), Island Press, Washington D.C.

Darwin, C. 1859 Origin of Species by Means of Natural Selection, John Murray, London.

Darwin, C. 1871 The Descent of Man and Selection in Relation to Sex, John Murray, London.

Darwin, C. 1881 The Formation of Vegetable Mould through the Action of Worms, with Observations on their Habits. John Murray, London.

Dawkins, R. 2017 Science in the Soul, Bantam Press

Dennett, D.C. 1995 Darwin's Dangerous Idea: Evolution and the Meaning of Life, Simon and Schuster, NY.

Dennett, D.C. 2008 Some Observations on the Psychology of Thinking About Free Will, Chapter 12 in Are We Free?: Psychology and Free

Will, edt J. Baer J.C. Kaufman and R.F. Baumeister, Oxford University Press.

Diamond, J. 1997 Guns, Germs and Steel: A Short History of Everybody for the last 13,000 years, Jonathan Cape.

Diamond, J. 2008 Vengeance is Ours: What can tribal societies tell us about our need to get even?, New Yorker, Annals of Anthropology. 
Diamond, J. 2010 Collapse: How Societies Choose to Fail or Succeed, Viking.

Goodall, J. 2010, In the Shadow of Man, Mariner Books.

Grinspoon, D. 2016 Earth in Human Hands: Shaping Our Planet's Future, Grand Central Publisher.

Grooten, M. \& Almond, R.E.A (eds) 2018 World Wildlife Federation 2018 Living Planet Report, Gland, Switzerland.

Habermas, J. 2001. The Postnational Constellation. Cambridge, Mass.: MIT Press.

Harari, Y.N. 2015 Sapiens: A Brief History of Humankind, Harper.

Harari, Y.N. 2017 Homo Deus: A Brief History of Tomorrow, Harper Collins.

Harari, Y.N. 201821 Lessons for the 21st Century, Jonathan Cape.

Hardin, G. 1993 Living Within Limits, Oxford University Press.

Harris, S. 2012 Free Will, Free Press, NY.

Hodgell, P.C. 2000 Seeker's Mask, Meisha Merlin Publishing.

Huxley, T. Man's Place in Nature, 1863, Williams \& Norgate.

Kuhn, T.S. 1957 The Copernican Revolution, Harvard University Press.

Kuhn, T.S. 1962 The Structure of Scientific Revolutions, 2nd Edt. Enlarged, Univ. Chicago Press.

Larson, E.J. 2006 Summer of the Gods: The Scopes Trial and America's Continuing Debate Over Science and Religion, Basic Books.

Lightman, A. \& Brawer, R. 1990, Origins: The Lives and Worlds of Modern Cosmologists, Harvard Univ. Press.
Lineweaver, C.H. \& Townes O'Brien, M. 2015, The Cosmic Context of the Millennium Development Goals: Maximum Entropy and Sustainability, chapter 2 in Nanotechnology Toward the Sustainocene, edt. T.A. Faunce, Pan Stanford Publishing Pte. Ltd.

Lucretius, $\sim 50$ BC De Rerum Natura (On the Nature of Things) Harvard University Press (1924) Loeb Classical Library.

Marks, J. 2009 Why I am not a scientist: Anthropology and Modern Knowledge, University of California Press.

Mikkelsen, T.S et al 2005, Initial sequence of the chimpanzee genome and comparison with the human genome, Nature, 437, 69-87.

Oerton, R. 2012 The Nonsense of Free Will: Facing Up to a False Belief, Troubador Publishing Ltd.

Oerton, R. 2016 The Cruelty of Free Will: How Sophistry and Savagery Support a False Belief, Matador.

Rees, M. 2003 Our Final Century, William Heinemann.

Rodrigue, B., Grinin, L. \& Korotayev, A. 2017 From Big Bang to Galactic Civilization: A Big History Anthology, Primus.

Russell, B. 1919 Dreams and Facts The Athenaeum nos. 4,642, 4,623 (Apr 18, 25 1919), 198-9, 232-3 Repr. Chapter 2, Sceptical Essays (George Allen \& Unwin, 1928) https://users.drew.edu/jlenz/brdreams.html.

Russell, B. 1928 Sceptical Essays, Routledge, London.

Russell, B. 1946 Philosophy for Laymen, Universities Quarterly 1 (Nov 1946), 38-49 Reprinted in Unpopular Essays, Chapter 2, George Allen \& Unwin, 1951. Online at https://users.drew. edu/ jlenz/br-lay-philosophy.html.

Sagan, C. 1996 The Demon-Haunted World: Science 
as a Candle in the Dark, Headline Book.

Segerstrale, U. 2000 Defenders of the truth: the sociobiology debate, Oxford: Oxford University Press.

Sutherland, W.J. 2003 Parallel extinction risk and global distribution of languages and species, Nature, 423, 276-279.

Trivers, R. 2000 Elements of a Scientific Theory of Self-deception in Evolutionary Perspectives on Human Reproductive Behaviour, Annals of the New York Academy of Science, April 2000, 907, 114-131.

Wallace, A.R. 1903 Man's Place in the Universe: A study of the results of scientific research in relation to the Unity or plurality of Worlds, Chapman \& Hall.

Weinberg, S. 1977 The First Three Minutes: A Modern View of the Origin of the Universe, Basic Books.

Wikelski, M. \& Tertitski, G. 2016, Living sentinels for climate change effects, Science, 352, 6287, 775776.

Wilson, E.O. 1975 Sociobiology: A New Synthesis, Harvard University Press.

Wilson, E.O. 1978 On Human Nature, Harvard University Press.

Wilson, E.O. 2013 Letters to a Young Scientist, Liveright. 
